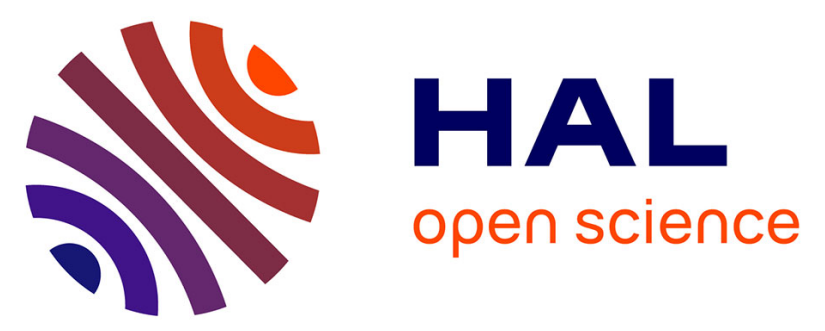

\title{
Industry 4.0: Evolution of the Research at the APMS Conference
}

Walter C. Satyro, Jose B. Sacomano, Márcia Silva, Rodrigo Franco Gonçalves, Jose Celso Contador, Gregor Von Cieminski

\section{- To cite this version:}

Walter C. Satyro, Jose B. Sacomano, Márcia Silva, Rodrigo Franco Gonçalves, Jose Celso Contador, et al.. Industry 4.0: Evolution of the Research at the APMS Conference. IFIP International Conference on Advances in Production Management Systems (APMS), Sep 2017, Hamburg, Germany. pp.39-47, 10.1007/978-3-319-66923-6_5 . hal-01666165

\section{HAL Id: hal-01666165 \\ https://hal.inria.fr/hal-01666165}

Submitted on 18 Dec 2017

HAL is a multi-disciplinary open access archive for the deposit and dissemination of scientific research documents, whether they are published or not. The documents may come from teaching and research institutions in France or abroad, or from public or private research centers.
L'archive ouverte pluridisciplinaire HAL, est destinée au dépôt et à la diffusion de documents scientifiques de niveau recherche, publiés ou non, émanant des établissements d'enseignement et de recherche français ou étrangers, des laboratoires publics ou privés. 


\title{
Industry 4.0: Evolution of the Research at the APMS Conference
}

\author{
Walter C. Satyro ${ }^{1}$ (0000-0002-0201-222X), Jose B. Sacomano ${ }^{1}$ (0000-0002-4877- \\ 3139), Márcia Terra da Silva ${ }^{1}(0000-0002-5314-4978)$ Rodrigo Franco Gonçalves ${ }^{1}$ \\ (0000-0003-2206-3136), Jose Celso Contador ${ }^{2}(0000-0002-7952-774 X)$ and Gregor \\ von Cieminski ${ }^{3}(0000-0001-9869-5055)$ \\ ${ }^{1}$ Paulista University-UNIP, Postgraduate Program in Production Engineering \\ Rua Dr. Bacelar, 1212, Sao Paulo, SP, Brazil, 04026-000 \\ \{satyro.walter,jbsacomano\} @gmail.com, marcia.terra@uol.com.br, \\ rofrancodosite.com.br \\ ${ }^{2}$ Paulista University-UNIP, Postgraduate Program in Administration \\ celsocontadoreterra.com.br \\ ${ }^{3}$ ZF Friedrichshafen AG, Friedrichshafen, Germany \\ gregor.cieminski@zf.com
}

\begin{abstract}
The research on Industry 4.0 is increasing in importance over the years due to the expectation that it represents a new industrial paradigm, increasing competitiveness to the industries that can adopt it. The objective of this paper is to study the main points of research on Industry 4.0, featured universities and research centers. Using methodology based on bibliographic review, we analyzed a total of 546 papers, which composed the proceedings of the International Conference Advances in Production Management Systems (APMS), in 2014 held in Ajaccio (France), 2015 in Tokyo (Japan) and 2016 in Iguassu Falls (Brazil) and selected 39 papers to make this research. The results revealed that Industry 4.0 is increasing in importance, broadening the field of research; some suggestions for future research are presented.
\end{abstract}

Keywords: Industry $4.0 \cdot$ Competitiveness $\cdot$ Productivity $\cdot$ Evolution

\section{Introduction}

A new industrial paradigm established on interconnectivity is already affecting industries, but in the near future, production will be able to exchange data directly with customers, supply chain, and other valuable stakeholders [1-3], in an integration never seen before. Based on high technology for automation, information and communication systems, machines and humans will be able to exchange data [4], opening new opportunities for the industries. This digital integration of resources was called Industry 4.0, an initiative of the German Government that launched the project at the Hannover Fair in 2011, when a public-private group was formed, with Henning Kager-

adfa, p. 1, 2011.

(C) Springer-Verlag Berlin Heidelberg 2011 
mann (Acatech - National Academy of Science and Engineering) and Siegfried Dais (Robert Bosch $\mathrm{GmbH}$ ) chairing a working group [5]. The objective was to create value, developing new business models, products and services, improving operational effectiveness and solving problems by the connection of the internal environment of the factory with the outside world [1, 4-6]. The initiative was followed by other countries that launched similar projects under other names, such as Produktion2013 in Sweden [7], Industrial Internet Consortium (IIC) initiative in USA [8, 9], Fimecc in Finland [7, 10], MADE in Denmark [7, 11], Smart Industry from the Netherlands [7, 12], Made in China 2025 in China [2, 13] and Japan's Robot Strategy in Japan [2, 14].

The objective of this paper is to study the main points of research on Industry 4.0, featured universities and research centers. To make this research we analyzed the proceedings of the International Conference Advances in Production Management Systems (APMS), which gather leading experts from industry and academia, from all over the world, in a period of 3 years (2014 to 2016).

\section{Literature Review}

\subsection{Industry 4.0 Project}

The concept that gave support to the Industry 4.0 project is the use of automated production system and robotics interconnected by information and communication system to exchange data with customers, suppliers, other members of the supply chain and valued stakeholders, so that machines, human beings and resources can interact with each other, making possible cooperation in real time, in order to support mass customization, increase competitiveness and reduce waste [2-7, 11, 15-16].

Industry 4.0 is based on three pillars: Cyber-physical systems, Internet of Things and Internet of Services [4]. Smart factory is considered a key feature of Industry 4.0 $[4,15]$, or the Industry 4.0 itself, also known as smart / cloud manufacturing [2, 6].

\subsection{Cyber-physical system}

Cyber-physical systems (CPS) are embedded systems that using software controlled sensors and actuators, controllers and smart objects, supported by information and communication technology, make possible data exchange between mechanical / physical production systems and human beings, allowing the interconnection between machine-to-machine (M2M) as well as human-to-machine (H2M) $[3,17]$.

\subsection{Internet of Things}

The Internet of Things (IoT) is the integration through the Internet of physical objects that have computational, sensing and actuation capabilities, making possible for them to be accessed globally and even controlled from anywhere in the world $[4,8,18]$. 


\subsection{Internet of Services}

Internet of Services (IoS) refers to new ways of relating to stakeholders, as well as to things, offering new services that can be discovered, hired, used and remunerated online, changing business models.

To Xin and Lai [19] Internet of Services (IoS) consists of services that are provided by the enterprise under the demand of the user, providing the capability of collaboration and interaction in personalized way. Accordingly to Buxmann and Ruggaber [20], it consist of sellers, consumers, users and an infrastructure for services that offer services, under a business model, using the Internet, that can be accessed by the participants via many different channels world-wide.

\section{$3 \quad$ Methodology}

We used bibliographic review to study the evolution of the research on Industry 4.0, choosing the proceedings of the International Conference Advances in Production Management Systems (APMS).

The importance of APMS is due to the fact that it is the official conference on production management of the IFIP Working Group 5.7 on Advances in Production Management Systems, which gathers leading experts of industry and academia from all over the world [21]. The study was based on the proceedings of 2014 held in Ajaccio (France), 2015 in Tokyo (Japan), and 2016 held in Iguassu Falls (Brazil). The papers presented in the Doctoral Workshop were not considered in this research. For this research we read the abstracts of all these three publications and selected the ones that made reference to: Industry, 4.0, smart factories, IoT, IoS, smart factory, smart / cloud manufacturing and other terms that could characterize any research on Industry 4.0, not limiting to analyze the papers submitted to the sessions with this specific subject. Table 1 illustrates the quantity of papers analyzed and selected to support this research

Table 1. Papers analyzed.

\begin{tabular}{rcc}
\hline APMS Intl. Conf. & Papers Analyzed & Papers Selected \\
\hline France (Ajaccio, 2014) & 230 & 4 \\
\hline Japan (Tokyo, 2015) & 163 & 20 \\
\hline Brazil (Iguassu Falls, 2016) & 153 & 15 \\
\hline TOTAL & 546 & 39 \\
\hline
\end{tabular}

\section{$4 \quad$ Findings and Discussion}

We identified the countries and university / research center / company that were contributing more to the research on Industry 4.0 at the APMS, based on the first author of each paper, shown in Table 2. 
Table 2. Quantity of papers per country per universities / research center / company, based on the first author of each paper.

\begin{tabular}{|c|c|c|c|}
\hline APMS & $\begin{array}{c}\text { Qty. } \\
\text { (papers) }\end{array}$ & Country & University / Research Center / Company \\
\hline \multirow[b]{2}{*}{$\begin{array}{l}\text { France } \\
(2014)\end{array}$} & 2 & Germany & University of Bremen \\
\hline & 2 & USA & $\begin{array}{l}\text { National Institute of Standards and Technolo- } \\
\text { gy (NIST) }\end{array}$ \\
\hline \multirow{17}{*}{$\begin{array}{l}\text { Japan } \\
(2015)\end{array}$} & 3 & New Zealand & The University of Auckland \\
\hline & 2 & Germany & RWTH Aachen University \\
\hline & 1 & China & Guangdong University of Technology \\
\hline & 1 & China & Zhejiang University \\
\hline & 1 & China & Wuhan University of Technology \\
\hline & 1 & China & Northwestern Polytechnical University \\
\hline & 1 & Germany & University of Bremen \\
\hline & 1 & S. Korea & Sungkyunkwan University \\
\hline & 1 & S. Korea & Pohang Univ. of Science and Technology \\
\hline & 1 & Sweden & Teknikföretagen - Assoc. of Mfg. Industries \\
\hline & 1 & Sweden & KTH Royal Institute of Technology \\
\hline & 1 & USA & Texas State University \\
\hline & 1 & USA & Georgia Institute of Technology \\
\hline & 1 & Japan & Kobe University \\
\hline & 1 & Mexico & Tecnológico de Monterrey \\
\hline & 1 & Slovak Rep. & FEI TU of Košice \\
\hline & 1 & UK & Cranfield University \\
\hline \multirow{12}{*}{$\begin{array}{l}\text { Brazil } \\
(2016)\end{array}$} & 3 & Norway & $\begin{array}{c}\text { NTNU-Norwegian University of Science and } \\
\text { Technology }\end{array}$ \\
\hline & 2 & USA & $\begin{array}{l}\text { National Institute of Standards and Technolo- } \\
\text { gy (NIST) }\end{array}$ \\
\hline & 1 & USA & Morgan State University \\
\hline & 1 & USA & Penn State University \\
\hline & 1 & USA & West Virginia University \\
\hline & 1 & USA & IGI, LLC \\
\hline & 1 & Germany & University of Bremen \\
\hline & 1 & Italy & Politecnico di Milano \\
\hline & 1 & Mexico & Tecnológico de Monterrey \\
\hline & 1 & Slovak Rep. & FEI TU of Košice \\
\hline & 1 & S. Korea & Korea Institute of Industrial Technology \\
\hline & 1 & Netherlands & University of Groningen \\
\hline
\end{tabular}

The research showed that academia uses different terms to refer to Industry 4.0, according to the different countries, as presented in Table 3. 
Table 3. Terms used in reference to Industry 4.0 per country.

\begin{tabular}{cc}
\hline Term used & Country \\
\hline Cloud manufacturing & China/Chinese authors, UK \\
\hline Smart manufacturing & USA, South Korea, Italy \\
\hline Industry 4.0 & Germany, Japan, Slovak Republic, Mexico, \\
& Norway \\
\hline Smart industry & Netherlands \\
\hline Produktion2030 & Sweden \\
\hline Cloud-based manufacturing & USA $^{(1)}$ \\
\hline
\end{tabular}

(1) We found this term in only one paper from the USA.

We analyzed these 39 papers to find their main areas of study, as shown in Table 4.

Table 4. Subject of study and areas of research on Industry 4.0.

\begin{tabular}{|c|c|c|}
\hline Qty. & Subject of study & Areas of research \\
\hline 9 & Architectures & $\begin{array}{c}\text { data flow, industrial gateway, } \\
\text { systems }\end{array}$ \\
\hline 6 & Information and communication systems & implantation, architecture \\
\hline 4 & Model / platform & \\
\hline 3 & Cyber-physical system & platform, production control \\
\hline 2 & Requirements Engineering (RE) & \\
\hline 2 & Software & components, reconfigurability \\
\hline 2 & Human-automation symbiosis & \\
\hline 1 & Process modelling & $\begin{array}{c}\text { knowledge share / ways to } \\
\text { share it }\end{array}$ \\
\hline 1 & Big Data & management systems control \\
\hline 1 & Digital / virtual manufacturing & \\
\hline 1 & Reference-model & \\
\hline 1 & System model & \\
\hline 1 & Innovation, research and education & \\
\hline 1 & Critical issues & \\
\hline 1 & $\begin{array}{l}\text { Networks of cooperation, manufacturing } \\
\text { components }\end{array}$ & \\
\hline 1 & RFID & \\
\hline 1 & Industry 4.0 and lean & \\
\hline 1 & Automation Technology selection & \\
\hline
\end{tabular}

\subsection{Discussion}

We could note the growing interest of academia in Industry 4.0; in 2014 (France) only $2 \%$ of the papers dealt with it, in 2015 (Japan) this percentage increased to $12 \%$ and maintained in $10 \%$ in 2016 (Brazil). 
Although we have understood that the evaluation of a leading country or a leading research center is not statistically significant due to the reduced number of the sample chosen, it is useful for presenting a general idea.

The USA was the country with the biggest quantity of papers, 10 in these three Conferences, followed by Germany with 6 in total, China with 4 and 3 papers from New Zealand. The University of Bremen (Germany) and the National Institute of Standards and Technology, NIST (USA) were distinguished with 4 papers each one in the three Conferences, followed by The University of Auckland (New Zealand) and NTNU-Norwegian University of Science and Technology (Norway), with 3 papers each.

The many different terms that academia used as references to Industry 4.0, identified in these 39 papers, confound and difficult new researchers in this field, with each country trying to differentiate a unique concept.

Another point of divergence was about the key components of Industry 4.0. In our research Cyber-physical systems (CPS) and Internet of Things (IoT) were key components accepted by all these authors. No paper dealing specifically with Internet of Service (IoS) was found in the proceedings, considered by some authors as key components $[15,16]$, although many authors made comments about IoS. Some understood big data and cloud computing as data service, but not an independent Industry 4.0 component [4]; others included them as key components. Smart factories were considered by some as key components $[15,16]$, while others saw smart factories not as component, but as Industry 4.0 itself.

Enterprise architecture with emphasis on data flow, systems and industrial gateway were the main subject areas of research, followed by information and communication systems, model / platform and cyber-physical system.

The difficult in promoting the integration among the many different physical components and/or the integration of their software were the most common related problems, which may be the reason of the main subject of these papers be related to enterprise architecture, information and communication system and model / platform. Cyber-physical systems were another important topic on Industry 4.0.

One paper addressed critical issues on Industry 4.0 [22]. We would like to propose for a possible "research agenda" of future APMS Conferences on Industry 4.0: the technical and financial implementation analysis of this new manufacturing paradigm, Internet security problems, IoS research, unemployment and training of new technical specialties, as this study did not identify much research in these areas. It would also be interesting to stimulate academia to publish critical papers on Industry 4.0, so that Governments, leaders, researchers and entrepreneurs, could analyze better the pros and cons and evaluate the risks and opportunities of the investments needed to adopt Industry 4.0.

\section{Conclusions}

The objective of this paper was to study the main points of research on Industry 4.0, featured universities and research centers. For this purpose we analyzed 546 papers 
that composed the proceedings of the International Conference Advances in Production Management Systems (APMS), in 2014 held in Ajaccio (France), 2015 in Tokyo (Japan) and 2016 in Iguassu Falls (Brazil).

APMS, the official conference of the IFIP Working Group 5.7 on Advances in Production Management Systems, was chosen for being considered one of the most important international conferences worldwide on production management.

The research showed that there was increasing interest of academia on Industry 4.0; the percentage of papers presented at the APMS increased from 2\% in 2014 (France) to 12\% in 2015 (Japan), maintaining 10\% in 2016 (Brazil). USA, Germany, China and New Zealand were the leading countries to present papers on this subject. The University of Bremen (Germany) and the National Institute of Standards and Technology, NIST (USA), presented the major quantity of papers on the three congresses, followed by The University of Auckland (New Zealand) and NTNUNorwegian University of Science and Technology (Norway).

This study also identified that enterprise architecture with emphasis on data flow, systems and industrial gateway were the main subject areas of research, followed by information and communication systems, model / platform and cyber-physical systems. The research showed that in these 39 papers authors from each country used different terms as references to Industry 4.0, confounding and making difficult initial studies on Industry 4.0.

The limitation of this research was that only APMS Conference papers were analyzed, therefore, for future studies we suggest repeating this research to analyze other international journals / proceedings and if possible study industrial case studies and compare with academic publications, in order to analyze differences in focus areas of academia and industry.

We would like to suggest also that critical papers on Industry 4.0 could be stimulated, so that entrepreneurs, leaders, Governments and researchers could better analyze the pros and cons and evaluate better the risks, benefits and opportunities to adopt Industry 4.0. We hope that the results of this research can be useful for decisions of IFIP WG 5.7 and for the organization of future APMS Conferences, such as topics in call for papers.

Acknowledgment We thank the Coordenacao de Aperfeicoamento de Pessoal de Nivel Superior (CAPES), Ministry of Education, Brazil, for the research grant, to Mrs. Dinan Dhom Pimentel Satyro for providing linguistic support, as well as to the blind reviewers who helped to improve this research.

\section{References}

1. Romero, D., Bernus, P., Noran, O., Stahre, J., Fast-Berglund, Å.: The operator 4.0: Human cyber-physical systems \& Adaptive automation towards human-automation symbiosis work systems. In: I. A. Nääs et al. (Eds.) IFIP 2016: APMS 2016 (2016)

2. Choi, S. S., Kang, G., Jung, K., Kulvatunyou, B., Morris, K.C.: Applications of the factory design and improvement reference activity model. In: I. A. Nääs et al. (Eds.) IFIP 2016: APMS 2016 (2016) 
3. Wiesner, S., Hauge, J.B., Thoben, K-D.: Challenges for requirements engineering of cyber-physical systems in distributed environments. In: S. Umeda et al. (Eds.) APMS 2015, Part II, IFIP AICT 460, pp. 49-58 (2015). doi: 10.1007/978-3-319-22759-7_6

4. Hermann, M., Pentek, T., Otto, B.: Design principles for industrie 4.0 scenarios: A literature review. In: Working Paper No. 01 / 2015, Technische Universität Dortmund, Fakultät Maschinenbau and Audi Stiftungslehrstuhl - Supply Net, Order Management, 1-15 (2015)

5. Sanders, A., Elangeswaran, C., Wulfsberg, J.: Industry 4.0 implies lean manufacturing: research activities in industry 4.0 function as enablers for lean manufacturing. Journal of Industrial Engineering and Management, 811-833 (2016)

6. Kang, H. S., Lee, J. Y., Choi, S-S, Kim, H., Park, J. H., Son, J. Y., Kim, B. H., Noh, S. D.: Smart manufacturing: Past research, present findings, and future directions. Intl. J. of Precision Engineering and Manufacturing-Green Technology, 3(1), 111-128 (2016)

7. Warrol, C., Stahre, J.: Manufacturing research, innovation, and Phd education on a national level - Produktion2030, a Swedish example. In: S. Umeda et al. (Eds.) APMS 2015, Part II, IFIP AICT 460, pp. 101-109 (2015). doi: 10.1007/978-3-319-22759-7_12

8. Kaihara, T., Kokuryo, D., Kuik, S.: A proposal of value co-creative production with IoTbased thinking factory concept for tailor-made rubber products. In: S. Umeda et al. (Eds.): APMS 2015, Part II, IFIP AICT 460, pp. 67-73 (2015). doi: 10.1007/978-3-319-22759-7 8

9. Industrial Internet Consortium, http://www.iiconsortium.org (2017)

10. Fimecc / Finnish Metals and Engineering Competence Cluster. https://www.fimecc.com (2016)

11. MADE - Manufacturing Academy of Denmark. We have one mission: world-class Danish manufacturing. http://en.made.dk (2016)

12. Smart Industry: Dutch industry fit for the future. https://www.smartindustry.nl/en/ (2017)

13. China Policy Institute: Analysis. Made in China 2025. https://cpianalysis.org/2016/10/26/made-in-china-2025/ (2016)

14. Japan's Robot Strategy, http://www.meti.go.jp/english/press/2015/0123_01.html (2015)

15. Kagermann, H., Wahlster, H., Helbig, J.: Securing the future of german manufacturing industry: Recommendations for implementing the strategic initiative INDUSTRIE 4.0 - Final Report of the Industrie 4.0 working group. acatech - National Academy of Science and Engineering, 1-82 (2013)

16. MacDougall, W.: Industrie 4.0: Smart manufacturing for the future. Germany Trade and Invest. 1-40 (2014)

17. Thoben, K-D, Pöppelbuß, J., Wellsandt, S., Teucke, M., Werthmann, D.: Considerations on a lifecycle model for cyber-physical system platforms. In: B. Grabot et al. (Eds.): APMS 2014, Part I, IFIP AICT 438, pp. 85-92 (2014)

18. Blair, G., Schmidt, D., Taconet, C.: Middleware for Internet distribution in the context of cloud computing and the Internet of Things. Ann. Telecommun. 71, 87-92 (2016)

19. Xin, L., Fan, Y., Lai, H.: An Efficient QoS Preference Oriented Recommendation Scheme for the Internet of Services. IN: L.M. Camarinha-Matos, L. Xu, and H. Afsarmanesh (Eds.): PRO-VE 2012, IFIP AICT 380, pp. 96-104, 2012.)

20. Buxmann, P., Hess, T., Ruggaber, R.: Internet of Services. Business \& Information Systems Engineering, Oct., 341-342 (2009). doi:10.1007/s12599-009-0066-Z

21. APMS 2107. http://www.apms-conference.org (2017)

22. Peng, T., Fang, S., Tang, R.: Resource utilization in cloud manufacturing - An energy perspective. In: S. Umeda et al. (Eds.): APMS 2015, Part II, IFIP AICT 460, pp. 379-387, (2015). doi: 10.1007/978-3-319-22759-7_44 